\title{
Obituaries
}

\section{Michael Bertrand Devas}

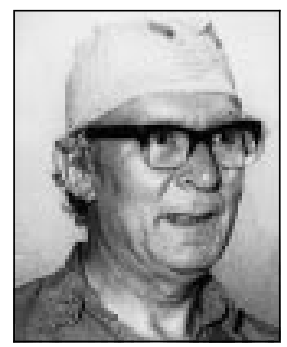

Former orthopaedic surgeon Hastings and professor of orthopaedic surgery Penang (b 1920; $q$ Cambridge 1943; MChir, FRCS), died from heart failure on 20 February 1999. He joined the Royal Air Force, serving in the Far East, and was appointed to Hastings in 1956. He invented what he called geriatric orthopaedics, which meant an urgent approach to the elderly and collaboration with geriatricians. "I'm only a humble carpenter," he said, "and I need a physician to tell me what's wrong with the patient." He started the world's first geriatric orthopaedic unit where orthopaedic surgeon and geriatrician worked together, conducting joint ward rounds. He emphasised the need for early operation for all, even the frailest, and immediate rehabilitation, with urgent attention to the patient's other medical and social problems. A favourite saying was, "The first step in rehabilitation is the first step." Michael established an orthopaedic workshop and found the funds and right people to staff it. Here were developed the Hastings hip, the Devas pin and plate, the Attenborough knee, and other prostheses. For many years he was an associate editor of the Journal of Bone and Joint Surgery and wrote Stress Fractures and Geriatric Orthopaedics. At the age of 61 he became the first professor of a new orthopaedic department in the Sains University at Penang, where he demonstrated that the principles of geriatric orthopaedics were as relevant to young road accident victims in Malaysia as to elderly people in Hastings. Michael was a brilliant fund raiser and worked indefatigably for the British Orthopaedic Association, raising $£ 1 \mathrm{~m}$ for the Wishbone Appeal, of which he was the director. He was a devout Catholic whose faith never wavered. Predeceased by two of his sons, he leaves a wife, Catharine; a son; and three daughters. [R E IRvINE]

\section{Thomas Patterson Scade Frew}

Former general practitioner Wickford, Essex, 1947-85 (b Wickford 1921; $q$ St Thomas' s Hospital 1945; DObstRCOG), $d$ 24 January 1999. After two years in the Royal Naval Volunteer Reserve he joined his father and brother in general practice. He was always a good games player, excelling in badminton, tennis, and hockey, but his main interest was golf, achieving seven holes in one. He leaves a wife, Caryll; a son and a daughter; and seven grandchildren. [James Frew]

\section{Adnan Sabih Jamil}

Chest and general physician James Paget's Hospital, Great Yarmouth $(b$ 1948; $q$ Baghdad 1972; FRCPGlas), died from an acute septicaemic complication of chronic lymphocytic leukaemia on 10 February 1999. Adnan was brought up in an old Baghdadi family when Iraq was a happier country. When the present era of unrest started in the early 1970 s he persevered with his training without compromise and then completed his postgraduate training in Britain, in Newcastle upon Tyne, Glasgow, and Swansea. In 1982 he became a consultant chest physician in the Al-Emir Hospital in Kuwait. At the time of the invasion of Kuwait at the beginning of the Gulf war Adnan was in Europe with his young family, when he discovered that he had leukaemia. He accepted this with his usual calm dignity and it did not stop him working hard until a few months before he died. In the 30 years I knew him I did not hear him express any animosity towards anyone, and he was full of praise to his colleagues in Great Yarmouth for their support and kindness. He leaves a daughter and a son. [A A A BAJALAN]

\section{Robert Leonard McMillan}

Former consultant anaesthetist Cumberland Infirmary and associated East Cumbria hospitals, 1948-82 ( $b$ 1918; $q$ Edinburgh 1940; FRCA), d 3 February 1999. Bob served in the Royal Army Medical Corps in the second world war, landing in Normandy with a casualty clearing station shortly after D Day. In 1945 he was transferred to the Far East, sailing with the invasion force for Malaya, and ending up in Singapore, where

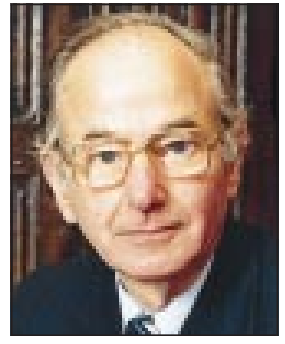

he married Monica, a nursing sister. As a consultant he was renowned for his down to earth and hands on approach. A past president of the North of England Society of Anaesthetists, he was a former chairman of the medical staff committee and served on the hospital management committee. His friendship with Professor Pask of Newcastle upon Tyne led to the introduction of the first anaesthetic respirator in east Cumbria, based on Pask's design and constructed by Bob in his workshop. His hobbies included clock making and sailing; he built his own boat. Predeceased by his wife, he leaves two daughters (one a doctor), and four grandchildren. [Peter StUART]

\section{Julian Vahrman}

Former consultant in chest medicine and infectious diseases ( $b$ 1913; $q$ St Bartholomew's 1936; FRCP; PhD), $d$ 13 January 1999. Before the war he worked as a ship's doctor, sailing to South Africa and Australia. He joined the Royal Army Medical Corps, following the liberating army on the day after the D Day invasion, and providing treatment through France and Germany. His lifelong commitment to peace began as a result of his experience at the Belsen concentration camp. He became consultant in charge of the Western Hospital in Fulham, specialising in diseases of the chest and later in infectious diseases. Julian did research on hepatitis B and in developing instrumentation for measuring carbon monoxide in the lungs for the clinics he ran to help people stop smoking. He continued to run clinics after retirement and this led to his $\mathrm{PhD}$ on smoking and the role of the tobacco companies in the Third World. This followed a MA in peace studies at the age of 78. Julian was active in the Ex-servicemen's CND, the Medical Campaign against War, the British Humanist Association, the Fabian Society, and the Labour party. He leaves a wife, Clare. [Clare Vahrman] 